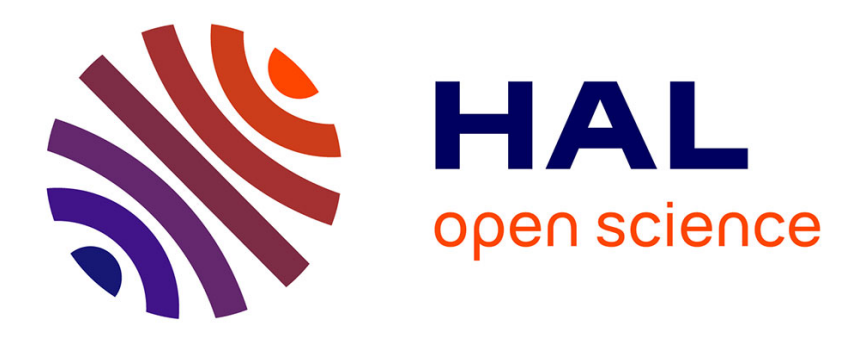

\title{
Women's Choices in Europe: Striking the Work-life Balance
}

\author{
Linda Hantrais, Peter Ackers
}

\section{To cite this version:}

Linda Hantrais, Peter Ackers. Women's Choices in Europe: Striking the Work-life Balance. European Journal of Industrial Relations, 2005, 11 (2), pp.197-212. 10.1177/0959680105053963 . hal-00570937

\section{HAL Id: hal-00570937 \\ https://hal.science/hal-00570937}

Submitted on 1 Mar 2011

HAL is a multi-disciplinary open access archive for the deposit and dissemination of scientific research documents, whether they are published or not. The documents may come from teaching and research institutions in France or abroad, or from public or private research centers.
L'archive ouverte pluridisciplinaire HAL, est destinée au dépôt et à la diffusion de documents scientifiques de niveau recherche, publiés ou non, émanant des établissements d'enseignement et de recherche français ou étrangers, des laboratoires publics ou privés. 


\title{
Linda Hantrais and Peter Ackers
}

Loughborough University, UK

\section{Women's Choices in Europe: Striking the Work-life Balance}

\begin{abstract}
The article presents evidence from interviews in France, Spain and Poland to explore how individual actors make choices about their work-life balance. It shows that choice is a complex, contingent, and relative concept, which is both facilitated and obstructed by public policies and working regulations. Despite differences in national and sub-national policy contexts, institutional and cultural norms and expectations, the article draws the conclusion that family-friendly issues need to be mainstreamed and that the concerns of families should be added to those of the state, trade unions and employers on the agenda for negotiating work-life balance. It is also argued that the focus and scope of industrial relations need to be rethought to take account of the gendered nature of employment relationships.
\end{abstract}

It is all too easy to tag equal opportunities onto the existing list of industrial relations 'issues' (Wajcman, 2000). However, this article argues that the focus and scope of industrial relations need to be rethought if we are to grasp the gendered nature of European employment relationships. Anglo-Saxon industrial relations theory took the male breadwinner as a generic 'worker', who was collectivized by his trade unions, thereby isolating the industrial relations system of bargaining between employers and trade unions from other policies of the state, the family, and the rest of society (Clegg, 1979; Dunlop, 1958). As Richard Hyman remarked of the UK at the 2004 European Industrial Relations Conference, one dimension of this approach was a strict separation of industrial relations as a discipline from social policy. While the former was dominated by male academics and focused on men and paid work, the latter was highly feminized and concentrated on women and welfare. The development of social policy at European level has meant that this academic division of labour, which did not exist to the same extent in some other EU countries, no longer made sense in the UK, particularly with the growth in the proportion of women in employment. The emergence of individual actors making 'choices', as reflected in the evidence presented in this 
article, also challenges the collectivism of past industrial relations thinking, whereby men and women acted almost exclusively through trade unions. As Ackers (2002a) has argued, all this calls for a reframing of the institutional context of working lives.

Dickens (1999: 9-10), writing from a UK perspective, calls for a 'threepronged approach to equality action', where legal regulation by the state, social regulation by trade unions and voluntary employer regulation, motivated by the 'business case', form a 'tripod' of policies that support equal opportunities. As she notes, 'business case arguments are inevitably contingent, variable, selective and partial and often underplay the wider context within which business rationales are having to be pursued'.

Our own European research on the work-family relationship ${ }^{1}$ underlines Dickens's fears about the 'insecure foundation' of voluntary business initiatives in the field of family-friendly policies. We concluded that 'the business case for harnessing human resources through family policies only works for certain employment groups, such as the more skilled and educated, during periods of full employment and labour scarcity' (Ackers, 2003: 227-8). In addition, it is necessary to address the specific needs of families and women and to respond to them flexibly. As Dickens (1999: 10) points out, employers often have scant understanding of employee needs, while 'organization-based equality agendas can do little for those outside organizations'. Trade unions offer a potential channel for 'voice' on these issues, but again our research found that unions often either lacked the coverage and power to affect policy or excluded family-friendly policies from a male breadwinner bargaining agenda (Ackers, 2003: 226).

All three prongs of Dickens's institutional reform strategy are prone to ignore individual choices and family coping strategies. Women's individual choices have been highlighted by Hakim (2000) in her 'preference theory'. In our view, choice is a relative, complex, and contingent concept, not easily grasped by large-scale quantitative studies. Our intention here is not to criticize preference theory, but to unravel the complex process whereby women in different European societies, at different stages in their life-course and in different socio-economic situations, reach decisions enabling them to strike an acceptable work-life balance. Our aim is also to contribute to a better understanding of the barriers to, and constraints on, choice and of the means whereby women, in particular, and men try to overcome them. The analysis is based on the observation that individuals can and do exercise varying degrees of control over life events. We argue that individual preferences and choices, and perceptions of choice and of constraints are determined to a greater or lesser extent by both endogenous and exogenous variables. The former include negotiations within households and the latter knowledge, awareness, legitimacy and availability of public policy, in conjunction with 
social values and cultural norms. We select three contrasting examples (France, Spain and Poland) to illustrate the ways in which individuals perceive the choices available to them and attempt to maximize outcomes for their work-life balance. ${ }^{2}$

\section{France: Avoir le beurre et l'argent du beurre, and More Besides $^{3}$}

Research shows that women are more able in France than in other EU member states to combine relatively high birth rates, a high old-age dependency ratio and non-marital family forms with full-time employment (Hantrais, 2003). Their working patterns vary little according to whether they have children. Attitude surveys consistently indicate that they attribute medium or high values both to work and to family life, strongly believe that being a housewife can be as fulfilling as paid work, but do not expect to have to choose between the two.

The French state is strongly supportive of family life and, more especially, of working mothers, and benefits and services are provided uniformly and consistently throughout the country (Hantrais, 2004). Objectively, external constraints on choice are minimized. The state has long promoted 'flexible' work-time policies, and it provides generous childcare infrastructures (including a high standard of strictly regulated crèche facilities) and leave arrangements, particularly for workers in the public sector, thereby, at least in theory, extending choice. Our respondents saw the state as having primary responsibility for children and older dependent people, rather than families themselves. State intervention in family life is highly legitimized, accepted and expected by family members, thereby reducing moral constraints. One woman who worked in the catering trade and was married to a divorcee explained:

Yes, the family is a question for the state to deal with. For childcare, crèches, family allowances. Lots of things. Improvements can only come from the state. We can't do anything ourselves. It's natural that the state should look after families, crèches and schools. It's natural because children are the citizens of tomorrow; they will be the ones paying taxes. They're the ones who will make the country function later on. That's why the state has to get involved. So, it's natural there should be facilities for children. It's the same with older people. It's natural for the state to look after them.

A divorced woman with three children, working as a nurse, likewise insisted: 'I think it's legitimate, because I don't know of any other system that would do it. I have always lived with the system we have, as a child, as a mother. It's become a way of life. In fact, it suits me that the state is involved. Otherwise I just couldn't manage'. A young male respondent 
with one child, living in an unmarried, cohabiting relationship, expressed a similar view: 'I think the state has a very important role to play. If we live in a democracy, we have to offer the same thing to all children without taking account of the purchasing power of parents. The state has a very big role to play. That's why I'm prepared to pay taxes. Many things depend on political decisions: education, family, children. That all seems obvious to me'.

Most of the French respondents, like this man, expressed a strong sense of social solidarity: they agreed that the state should redistribute resources to the less privileged members of society. They also said they rely on the state to take decisions about family matters such as custody or alimony following a divorce. The public accepts that the courts should intervene to ensure that parents who are unable to manage their own affairs do not squander family benefits. Respondents expressed a preference for services and facilities rather than cash benefits, on the grounds that they are more likely to reach children instead of being appropriated by another member of the family.

A recurring theme in the interviews was that the state does not do enough, although those respondents who had lived and worked abroad recognized the advantages of the French system and considered themselves 'fortunate' to be living in a country that makes such good provision. One woman with four children, whose husband was a senior civil servant used to being posted abroad, explained: 'We know what family policy means in France. We try to manage without it because we know that if we go abroad we won't find the same thing. We won't be as fortunate as we are here. We might go to live in countries where we would not have the same support'. A respondent with an Italian partner cited the same reason for returning from abroad: 'Before the birth of my child, I worked as a freelance journalist, so I was free and I lived abroad. I came back to France when my daughter was a year and a half old because family life was very difficult in Italy, and family policy left much to be desired.'

A number of respondents conceded that state intervention is legitimate for so long as it translates into the provision of benefits and services that create opportunities for choice. They do not want to feel that the state is driving them towards a particular line of action. A few respondents were concerned that the state might be taking responsibility away from people. A clear consensus emerged that the state should not intervene to encourage couples to marry or to have children. As one male respondent put it with regard to the decision to have children: 'It's a matter of individual choice. The state has nothing to do with it. It's not the role of state, even if economic or demographic arguments can be made... I think that wanting to have children depends on a much wider context and the state of the economy ... I don't think it's right to try and encourage people to have children. That's what happened in the 1920s'. 
Many respondents were aware of the demographic problems associated with population decline and ageing, and they accepted that society has a responsibility for its own future, but the principle of enabling people to decide about their own lifestyles was staunchly upheld. A female respondent with a reconstituted family and who was not in paid work felt people were subjected to too much institutional and ideological pressure: 'for me the state is a perverse institution ... The state forces people to get married. It forces them to have children. I believe that the institution of the family destroys couples, and you really have to put up a lot of resistance to hold out against all the institutional and ideological pressures ... On the one hand, the state is trying to make you have children, and on the other, there's not enough provision for childcare'.

The interviews showed that public expectations are constantly rising, but individual choices are rarely perceived as directly determined by policy. The main concern of respondents is to ensure they receive their entitlements, and they generally do. One couple, both students, described how they had calculated whether it was in their best interests, in terms of benefits and taxes, to marry or to continue in unmarried cohabitation when they have children. Others had decided the number of children on the basis of their working and living conditions and access to childcare services. The decision whether to go out to work or stay at home had been discussed and negotiated in only a very small number of cases, although most parents told how they tried to maximize the available benefits and services to enable them to pursue their occupational careers when they had children and to make everyday life as easy as possible. For most women, it was a foregone conclusion that they would continue working when they had children. Despite the relatively generous childcare services and after-school provision in nursery schools, ${ }^{4}$ several respondents complained of difficulty in finding a place in a crèche and advocated more flexible opening hours to accommodate parents with non-standard work schedules.

Whereas they rely on the state implicitly, respondents were more suspicious of any form of social control that employers might exercise over families and the private lives of employees. They expect employers to show understanding of the constraints families impose on their members as workers and to ensure that work does not adversely affect family life, mainly by providing flexible working hours and arrangements. Faced with the choice between stopping work to look after young children (albeit with the guarantee of reinstatement) or reducing working hours, respondents with young children opt heavily for rearranging working time rather than interrupting employment. Most of the criticisms levelled against employers concerned the negative effects of imposing part-time and inconvenient working hours, and employers were held responsible for creating a stressful environment. But it was not 
the role of employers to provide services to make it easier to combine private life with work, as a younger male respondent, living in an unmarried, cohabiting relationship with one child, explained: 'No, I don't think this is an issue for employers. I don't see why employers should try to improve the situation... It's up to the state to provide facilities for children. That's the job of the state'.

Since the data point in 2000, when most of our socio-economic statistics were collected, working hours have been reduced in France. Women should, therefore, be in a better position to realize their preferences with regard to working arrangements, for example, by leaving work earlier to pick up children from a crèche. The reduction in working time has not, however, been sufficient to enable parents to achieve a more satisfactory work-life balance if they are in sectors that do not operate standard and predictable working hours (Fagnani and Letablier, 2004).

The role of the state in France, as perceived by our respondents, seems to be that of an agent creating the conditions needed to make family and work compatible, while leaving individuals free to choose between the available options. The state and the public are engaged in a process of constant negotiation, where the main bargaining tool is women's ability and willingness to act as mothers and workers for the future good of the nation. Culturally and socially (and historically), women have been conditioned not to have to choose between children and paid work, but nor do they expect to have to find solutions for themselves or to negotiate them with their partners. They do want to safeguard freedom of choice to organize their family life as they think fit, but they are ready to delegate child (and increasingly elder) care to the state to help them achieve an optimal work-life balance.

\section{Spain: Nadar y guarda la ropa, But First You Need to Teach Yourself to Swim}

As in other Mediterranean states with less developed welfare systems, women in Spain combine low birth rates with more traditional family forms and low employment rates (Hantrais, 2003, 2004). In addition, women in employment generally work full-time and relatively long hours, irrespective of whether they have children. Those who work parttime often do so because they cannot find a full-time job in the formal labour market. Spanish women, unlike those in France, assign only low or medium value to family life. They reject the idea that women really prefer home and children, and do not think that women need children to be fulfilled or that being a housewife can be as satisfying as paid work. They clearly believe that mothers should have the option of paid work and that children do not suffer if their mothers are out at work. 
Low labour force participation and low birth rates therefore appear to reflect constraints on choice and limited opportunities in the labour market. Public investment in family support has been very low in Spain, with the result that families continue to rely heavily on their own networks. The social protection system has been described as regressive with regard to women's rights, making them discretionary recipients rather than entitled contributors, because of their poor access to the labour market (Mangen, 2001). Hostile business policies, unhelpful working, school and shopping times and poor public childcare services combine to present daunting obstacles for women seeking employment.

In the absence of public infrastructures, Spanish women in all but the higher income groups depend heavily for childcare on the extended family, particularly grandmothers, if they are in employment, but this arrangement is affected by the decline in the traditional, reciprocal family contract that had supported old and young dependants. Women in all social classes commented that public childcare provision was totally inadequate and only available to the very poor. A woman aged 36, working part-time as a nurse, and with two young children complained that: 'there are very few public crèches ... and long waiting lists. It works according to your income and a point system. If you live in the neighbourhood, you get a certain number of points. You need to have a very low income'. Another respondent, a single mother, found it hard to combine work and looking after a child even though, as a teacher, she had long holiday periods. She relied on her parents to help: 'good thing I had my family, because I got no help from the City Council'. A 38-year-old woman, with three children, painted a similar picture: 'The help available today is insufficient and ridiculous compared with that offered by other European governments. Most of our friends have opted not to have kids, or to have only one. So there's a low birth rate in Spain. What? Are they surprised?'

Many women had no option but to try and work round the system and find compromises: 'It's difficult when you have children and want to find a job you like and which suits your timetable. For example, I'm interested in working mornings because if I have a daughter then I want to bring her up and be with her. That's very important for me. The problem is that this is not provided for in social terms.'

Employers have not filled the policy vacuum left by the state, and were strongly criticized for failing to introduce family-friendly policies. Employment within public administration is the exception, allowing workers greater flexibility and showing more sensitivity to women's problems, perhaps because of the high percentage of female employees. As one nurse in a public-sector hospital recounted: 'I don't even think about working in the private sector, because working hours would just make it too hard to look after the children. Work in the public sector is a straight shift, usually in the mornings'. 
Workers in private companies must ask for leave to look after their children, and are frequently obliged to make up time lost. Reconciling work in the private sector with child-rearing was shown to be problematic despite protective legislation, as explained by one woman in a cohabiting relationship:

In January 1998 I started to work as a sales assistant in a company. I signed a provisional contract for three months, which they renewed for a further six months. In July I happily informed the company that I was pregnant and, on 19 October, my boss informed me that they would not be renewing my contract. A few days earlier the front pages of the newspapers had been talking about a European Union directive that 'protects' pregnant women.

'What do we mean when we say that women nowadays are independent?', she continued. 'If we are discriminated against at work, the medium that would allow us to be really independent, what independence are we talking about? I don't believe that politicians are even remotely interested in solving the low birth rate or the incompatibility between work and childcare'.

Neither living nor working conditions are seen as conducive to family life. Many respondents referred to the increasing precariousness and scarcity of work, the rising cost of living, the lengthening of university studies and the rising cost of housing, which made them reluctant to form a couple or have children. One married woman with two daughters of 25 and 28, both of whom were living at home, recounted:

Now I see that people don't think of having children so soon. I became a mother for the first time when I was 25 , and I see my daughter and her friends at that age, and no way! I began to be economically independent when I was 19, and the same was true for my husband. Now people have to depend on their parents for longer, and can't even think of having children ... It was really easy for me, work wise. I would work in different places, but I kept my salary. It's not like that now, because companies hire you on temporary contracts ... and that doesn't give young people any sort of security with which to rent accommodation, and much less so to buy a home. Renting is expensive, and you can't pay a mortgage on a temporary contract. People have to think about having their children after the age of 30 , because they first need employment stability.

The irony is that women in paid work now depend on the unpaid resource that they themselves used to provide. As one single mother commented: 'the secret support is the family. The government offers no economic aid because the solution is that parents and family are supposed to help you ... [But] the family of old no longer exists ... Nowadays there are not two children, as having just one child is almost a luxury, the mother works, so does the father, and they're separated anyway'. Several 
respondents had moved house to be near to their relatives and to be able to turn to them for support when needed. One of them explained: 'When my son turned four, we came to live in this small town. My in-laws let us use this house, and they live next door. Since we both work, we needed this support from the grandparents in order to take care of our son ... His grandparents go and collect him from school. They make his lunch, and take him back again'. An unmarried, cohabiting respondent with a young daughter explained how she relied on help from family and friends: 'We bought the flat in this area because it's the neighbourhood we were both brought up in. That's important because all our friends are here, and it's where we grew up. There's good public transport, hospitals, and my parents live very close by. They can take care of our daughter and, when they're older, they'll have me close by'.

It was clear, however, that the intergenerational contract was breaking down and that, in the future, grandparents would not want to look after their grandchildren, and children would no longer expect to provide care for older people. One woman in a multigenerational household signalled that the burden on families needed to be reduced: 'There's a real need to help these young parents in order for them not to be so dependent on the grandparents. When I become a grandmother, I'd like to take care of my grandchildren at weekends once in a while, or during holidays. But not as an obligation; I think I would feel trapped. I'd like to be able to relax when I retire'. A widow looking after her grandchild while her daughter was out at work commented on her expectations for old age: 'My daughters and sons-in-law all work, and I have psyched myself up to face the idea of living in a home when I am older. In the past, this would never have crossed your or your mother's mind. I looked after her at home. The family atmosphere for the elderly and the youngsters was totally different'.

In terms of 'choice', the result was a clear gap between the number of children women were having and their ideal family size. As a married woman with a 'large family' of three children explained:

At least two children is the ideal. More than three seems to be too many just because of housing, or the size of cars. Just one child seems to be not enough. If you're an only child, and you marry an only child, and then you have an only child, I mean, what family have you got? No nieces and nephews, no cousins. Concerning the type of legislation that would help families to achieve the ideal size, I think that flexible hours are really important. It seems like school and parents' employment work against each other. Companies are not overly willing to have mothers taking care of their kids. I don't think the state does much to try to reconcile the school timetable and people's working hours.

Even this modest ideal of two children appeared unattainable according to an unmarried cohabitant with a four-year-old daughter: 'I would not 
like my daughter to be an only child. I would like her to have brothers and sisters, but that is very complicated in practice. We have a small house and, if we have another child, my parents will be too old to look after the baby while I'm at work. In this country bringing up children is like an obstacle race'.

These quotations are representative of the views expressed in the interviews. Spanish mothers want to be able to undertake paid work and are not worried about the effects on children, but the system discriminates in favour of male breadwinners. In the absence of support from either the state or employers, and with declining scope to rely on family networks, 'reconciliation' for most women means stunting both family life and employment opportunities.

\section{Poland: Trzymać dwie sroki za ogon, and to Let Go of Both}

In contrast to the other two countries, the Polish picture is a mix of very high and very low ratings for the socio-economic indicators we examined (Hantrais, 2003, 2004). Despite the strong attachment to family values and public policies prohibiting abortion and restricting access to contraception, the fertility rate had fallen to a very low level in 2000. Female life expectancy and old-age dependency were low in relation to the EU15 average, and family life had not been deinstitutionalized to the same extent as in many of the other former communist countries. Polish respondents believed more strongly than those in other countries that what women really want is home and family and that children suffer if their mothers are in paid work. In combination, these indicators suggest that Polish women do not have much choice about the way in which they organize their lives, and this was borne out by the interviews.

Many respondents were very critical of the present situation in Poland. Although they may not have had much freedom of choice in the past, older respondents looked back nostalgically to the period before transition, as illustrated by a comment from a married woman with two children:

There was no unemployment at the time. There were no serious financial problems like those families are suffering from nowadays ... We didn't think in terms of whether [family life] was economically viable. We just wanted to be together. Maybe that's why we didn't take money into account. We were psychologically comfortable. You weren't troubled by the thought that you could be sacked, that you could be deprived of housing, of money in the future.

Respondents such as these stressed the fact that, in the 1980s, public policy provided a more favourable climate for parenting and finding work was not an issue. 
Although Poland has shared the experience of socialism and transition with the other CEE countries, the socio-cultural context is distinguished by the abiding influence of the Catholic Church on attitudes towards family life, the legal framework and the provision of benefits and services. Religious values remain the most important single factor affecting the decision to get married. A married women, who had had her first and only child at the age of 19, claimed: 'I'm a Catholic and I'd be ashamed to live in any other way'. Another woman, in her fifties and with three children, maintained that 'religion always carries some values with it, and it seemed only natural to me that a relationship should be legalized'. Another married woman with two children also felt she had no option: 'I'm a Catholic and my family are Catholic. I've been brought up in this spirit and I haven't even thought that you could live together without marriage ... It would make me unhappy, I guess, if I didn't live in accordance with my conscience'.

Although more young couples today are living together without being married, social pressure is strong for couples to marry, and the decision may be precipitated by an unexpected pregnancy and the desire for the child to be born to a married couple, particularly in the rural environment. A married woman with seven children working on the family farm commented that 'people see it differently when you get married first and then have a baby than when you're not married and have a baby'.

On the whole, institutional factors such as family law and access to benefits and social services were not taken into account in decisions about family life. Families are considered to have primary responsibility for their members. Respondents know they can rely on assistance from their family, as stated by a young divorced woman, who described herself as a Catholic: 'When I was getting married, I dreamed about being financially independent, but I took into account that, if something went wrong, I could count on my parents'.

The role of governments today is to create the necessary economic and employment conditions so that families can function effectively and so, in turn, can society as a whole. The state is expected to help families shoulder the burden of caring for the weaker members of society, but respondents had no confidence in their government to provide for their basic needs, as testified by the same woman: 'your baby's born, and the child benefits you get will suffice to buy nappies ... You receive these few pennies from the state, and ... you don't know what to spend this benefit on: food, school, clothes or books ... If you don't earn a lot, nothing will make it possible for you to achieve optimum family size'.

In recent years, the decision to live in a formal married relationship has been increasingly influenced by economic and financial considerations, particularly employment and unemployment. A respondent explained that she married 'for economic reasons mainly. We were going to apply 
for a student family grant [for which only married couples are eligible]. And also, my family bought us a flat. We had to pay some money back to them, and [the husband] said he would help me pay this debt, and I wanted to give our relationship some legal certainty, so that it wouldn't be that we live together and he pays for it with his money'.

The involvement of employers in family affairs should, according to respondents, be limited to observing labour law. Employers are not expected to take account of the private lives of employees and are strongly criticized for discriminating against women as mothers. Even marriage is presented as threatening job opportunities because, in a slack labour market, employers want to avoid appointing women who may take time off for children. According to the same respondent: 'I knew if I was married, ready to have children, this would be seen as a disadvantage. I was afraid my potential employer might say "you are at such an age, you have a husband, it's high time for you to have children, so we won't give you a job" ... It's easier for me to find a job now. No one fears I will have a baby. It's awful, but the first question you're asked by an employer is "are you going to have children and when?"

A variety of factors influence the decision whether to have children and how many. The availability of social benefits and public support services was not cited as the primary motive for having children; benefits are in any case pitched at such a low level that they do not provide an incentive for family-building. The majority of respondents had made a conscious decision whether to have one or two children, taking account of their financial situation, income from employment and the cost of housing and of raising children. An older married man without children argued that 'because of the difficulties in the labour market having a child means sacrifices . . . It's much easier not to have children. We're living in the days of drastic choices'. He went on to describe the most feasible living arrangement as one that left no place for family-building: 'These days, in Poland, the optimum relationship, it seems to me, would be the relationship between two independent partners, who have their interests, are professionally active, are capable of living independently as individuals ... This seems to be the model best applicable in the unstable times we live in'.

As in several other post-communist countries, the state intervenes with the explicit objective of encouraging families to have more children. Previous Polish governments extended maternity leave and introduced additional allowances for large families, in combination with measures to curb abortion and contraception. However, three or more children are not generally planned. The female respondent with seven children explained: 'I knew it would be more and more difficult to provide for these children, but I couldn't have an abortion. Let it be as it's meant to be. Good God gives you a child, so he might give you the means to provide for the child'. 
To the extent that couples felt free to choose parenthood, the precondition for embarking on family life was stable employment that guarantees a decent income, and this was a recurring theme throughout the interviews. For a widow living alone with two teenage children, 'This is not about benefits, this is about work. Everyone should have a job. If everyone had a job, child benefits wouldn't be required. Everyone would be able to earn enough for a living'. A married woman with two young children maintained that 'benefit is a passing thing. You can claim it for two or three years. When a woman takes care of a baby, she should receive benefit, but it's the prospect of taking up work later on that gives her hope, some chances to get by'. A male respondent, who had never married, argued that men felt undermined in their traditional male breadwinner role. 'There's no work, no prospects of finding a job in the future. Men are afraid to set up home; they can't afford it ... They can't earn a living being single, not to mention providing for a family. The situation in Poland doesn't encourage people to form a family'.

The majority of the respondents were in employment when they made decisions about their family life. Women described how, before transition, giving birth to a child did not curtail employment opportunities. After delivery, they made use of their parental rights and took maternity leave. As a rule, they took between a few months and a year, using only part of their entitlement, and then returned to the same workplace. They went back to work mainly for financial reasons. Where possible, grandparents helped them raise their children. Otherwise, spouses shared childcare responsibilities until the children went to nursery school. They rarely used a crèche. Work in shifts, availability of nursery schooling, and help from parents made for a well-organized family life, and the sharing of responsibilities made it possible to combine paid work and family responsibilities. Very few respondents did not return to work.

By contrast, balancing the two is now extremely difficult. One married female respondent who had had her two children when she was in her thirties compared the two situations:

A woman takes sick leave and people at work frown at her. In the 1980s, it wasn't that bad, it wasn't taken into account when you were taken on; there was plenty of work. If a woman went on sick leave for a month, it didn't count against her. Nowadays, when a child is ill and a woman takes leave she can be sacked. Again, when a woman takes up work after having been on childcare leave, she works for a month or two and there's a job cut, and she's the first to be sacked. And the worst situation is when she is married and her husband is unemployed, so she returns to work and he is at home with a child. And she, being the only provider for the family, is sacked.

The preoccupation with job security, employment stability and a living 
wage means that the options available in Polish society today are severely constrained by economic factors. The priority for respondents is not, however, the provision of more and better benefits and services to extend choice and enable them to strike a work-life balance. They want secure jobs and a living wage.

\section{Choice in Context: State, Employers, Unions, and Individual Families}

As Dickens (1999: 10) implies, for most women in employment the problem may not be the 'glass ceiling', but the 'sticky floor'. This was clearly apparent from our interviews. Hakim (2000: 4-6) distinguishes between three 'preference groups': 'home-centred', 'work-centred', and 'adaptive' women. Our research found, like hers, that most women fall into the adaptive category, but with economic opportunities, national policy provisions and culture strongly shaping the choices they are able to make. Decisions about the balance between child-rearing and paid work are contingent on a combination of factors, largely outside the control of individuals: public policies and working regulations may both facilitate and obstruct choice. Our three contrasting examples of countries with very different institutional, economic and cultural legacies show how societal forces condition the process of choice.

Most of the respondents seemed to be heavily influenced by cultural norms and practices. There were different perceptions of what women have a right to expect from society and, more specifically, from state, enterprise, and family. Even among women who, objectively and from a comparative perspective, appear to have a high degree of individual discretion, as in France, a recurring theme was the demand for more provision and greater choice. The examples of France, Spain and Poland suggest that 'choice' as understood subjectively in relation to work-life balance is embedded in very different national and sub-national policy environments, cultural norms, and expectations. 'Choice' is something complex and elusive that emerges from the constraints, opportunities and ideologies of a particular time and place.

From a broader industrial relations perspective, this research gives some clues about what a gendered analytical framework would look like. Whereas traditional qualitative industrial relations research tends to work from the organization outward, we did not take the organization as a level of analysis. Instead, we looked at the impact of EU and national policies, interviewed policy actors at national level (including employers and trade union representatives), and then went straight to the choices and strategies of individuals and families. In this way, we travelled from social policy into work, rather than the other way round. 
Organizational analysis is important, but if industrial relations takes the worker-employer 'employment relationship' as its core, our study indicates that it will not be enough to suggest a 'semi-permeable membrane' (Edwards, 2003) between work and family life. According to this approach, only at certain moments and with certain policies (for example, on equal opportunities and family friendliness) will the membrane open to family choices and policies. On the contrary, we would suggest that working arrangements are endemic to the choices that families make and vice versa. For instance, if joint regulation is to be a conduit for equal opportunities, family-friendly issues need to be a mainstream part of the bargaining agenda (Ackers, 2002b, 2003). Even at EU and national levels, policies need to be shaped by an understanding of women's (and men's) family needs, not just by narrow and short-term business needs. So Dickens's (1999) tripod must perforce become a 'quadripod', adding the active individuals that make up a family to the agencies of the state, trade unions, and employers and also recognizing families as social actors.

\section{NOTES}

1 The project, entitled 'Improving Policy Responses and Outcomes to Socio-Economic Challenges: Changing Family Structures, Policy and Practice' (http://www.iprosec.org.uk), was financed by and prepared for the European Commission, DG Research. The contents of this article do not necessarily reflect the opinion or position of the Commission. The research covered eight of the EU-15 member states and three Central and Eastern European (CEE) countries. It combined secondary analysis of socio-economic data, interviews with political, economic and civil society actors, and small-scale surveys (Hantrais, 2003).

2 In 2001-02, 41 interviews were carried out in France, 52 in Spain, and 50 in Poland, with men and women representing different family types, age groups, and socio-economic categories. The national research teams used a semi-structured questionnaire to probe knowledge, perceptions, and experience of the impact of public and company policy on decisions taken about family and working life.

3 Our discussion is framed around popular imagery often used to describe women's strategies to pursue both paid work and family life. Avoir le beurre et l'argent $d u$ beurre is functionally equivalent to the English expression 'to have your cake and eat it', while nadar y guarda la ropa in Spanish means 'to swim and keep your clothes on' and trzymać dwie sroki za ogon in Polish translates as 'to hold two magpies by the tail'.

4 Pre-schooling (école maternelle) begins at the age of two, with opening hours from 08.30 to 16.30 . Almost all children aged between three and four attend, and services are available to look after children before and after school hours. 


\section{REFERENCES}

Ackers, P. (2002a) 'Reframing Employment Relations: The Case for Neo-pluralism', Industrial Relations Journal 33(1): 2-19.

Ackers, P. (2002b) 'Economic Policy Actors', Comparing Family Policy Actors, Cross-National Research Paper 6(3): 14-28.

Ackers, P. (2003) 'The Work-Life Balance from the Perspective of Economic Policy Actors', Social Policy and Society 2(3): 221-9.

Clegg, H.A. (1979) The Changing System of Industrial Relations in Great Britain. Oxford: Blackwell.

Dickens, L. (1999) 'Beyond the Business Case: A Three-Pronged Approach to Equality Action', Human Resource Management Journal 9(1): 9-19.

Dunlop, J.T. (1958) Industrial Relations Systems. New York: Holt.

Edwards, P.K. (2003) 'The Employment Relationship and the Field of Industrial Relations', in P. Edwards (ed.) Industrial Relations: Theory and Practice, pp. 1-26. Oxford: Blackwell.

Fagnani, J. and Letablier, M-T. (2004) 'Work and Family Life Balance: The Impact of the 35-Hour Laws in France', Work, Employment and Society 18(3): 551-72.

Hakim, C. (2000) Work-Lifestyle Choices in the 21st Century: Preference Theory. Oxford: Oxford University Press.

Hantrais, L. (ed.) (2003) Comparing Family Change and Policy Responses in Europe, Cross-National Research Papers 6(7).

Hantrais, L. (2004) Family Policy Matters: Responding to Family Change in Europe. Bristol: Policy Press.

Mangen, S.P. (2001) Spanish Society after Franco: Regime Transition and the Welfare State. Houndmills: Palgrave.

Wajcman, J. (2000) 'Feminism Facing Industrial Relations in Britain', British Journal of Industrial Relations 38(2): 183-201.

LINDA HANTRAIS is Professor of European Social Policy in the European Research Centre at Loughborough University.

ADDRESS: European Research Centre, Department of Politics, International Relations and European Studies, Loughborough University, Loughborough, Leicestershire LE11 3TU, UK. [e-mail: I.hantrais@Iboro.ac.uk]

PETER ACKERS is Professor of Industrial Relations and Labour History at Loughborough University Business School.

ADDRESS: Business School, Loughborough University, Loughborough, Leicestershire LE11 3TU, UK. [e-mail: p.ackers@lboro.ac.uk] 